\title{
Vascular Implant Infection
}

National Cancer Institute

\section{Source}

National Cancer Institute. Vascular Implant Infection. NCI Thesaurus. Code C78710.

An infectious process originating from an implanted vascular device. 